\title{
DEMOGRAPHIC CHANGES AND THEIR IMPACT ON THE LABOR MARKET AND EDUCATION SYSTEM. THE RESULT OF A NATIONWIDE MODERATED DISCUSSION
}

\author{
Ryszard MARSZOWSKI ${ }^{1 *}$, Krzysztof GOGOLA ${ }^{2}$ \\ ${ }^{1}$ Central Mining Institute, Katowice; www.gig.eu; ORCID 0000-0002-2855-7121 \\ ${ }^{2}$ Central Mining Institute, Katowice; www.gig.eu; ORCID 0000-0003-4099-3484 \\ * Correspondence author
}

Purpose: the main goal of this article is to determine whether demographic changes threaten the development of the labor market and education system.

Methodology: theses and research questions were verified by means of a group interview, carried out with a target group of experts representing nurses and midwives in their trade union organizations. The basic recording technique for the interview was sound and audio recording. Findings: demographic changes will affect the future shape of education and the labor market. The most serious challenge is the need to adjust education levels to the age structure of the population resulting from demographic change. There is a need to improve people's competences by promoting the idea of lifelong learning. As a result of aging, labor resources will come from a much older population than today. This is a challenge of updating current training programs to adapt them to aging societies - and Europe's competitiveness will depend on the quality of their employment and the efficiency of their work.

Originality: knowledge presented in the article indicates that special attention should be paid to supporting the smooth transition of young people from education stage to the labor market, as well as ensuring the longest possible economic activity of people over the age of 50 . Considering the above, it should be clearly stated that demographic, economic and social trends have led the period of economic activity of Poles and citizens of most European countries being extended.

Keywords: demographic change, labor market, education.

Category of the paper: research paper. 


\section{Introduction}

The main objective of the qualitative field research conducted among representatives of national trade union organizations was to determine the impact of demographic changes on the domestic labor market and the education system at every level of education ${ }^{1}$. It is worth noting that, in light of the fact that, according to demographic forecasts, by 2030 the number of people of working age in the European Union will drop by almost 21 million, the population of young Europeans will decrease by $20 \%$ over the next 20 years. This change is one of the key challenges for modern Europe in the field of education. The European Expert Network on Economics of Education (EENEE) highlights this very clearly, as in the report titled "The future of European education and training systems: key challenges and their consequences" demographic change is placed first among the four key challenges for education and training systems (Schlotter et al., 2008). Subsequently, research results are of particular importance and show that $60 \%$ of new types of work performed in the $21^{\text {st }}$ century will require skills that are currently only possessed by $20 \%$ of potential employees. Therefore, the challenge is to promote modern attitudes and awareness of the fact that, in the industrial age, moving away from the dominant way of thinking is necessary and inevitable, because only turning to the future - by caring for our own development - can guarantee success (Matusiak, 1998, p. 33).

Representatives of nurses and midwives trade unions, directly or indirectly connected with the management of trade union organizations in the public health sector, were invited to carry out a group interview - as mentioned before. The type of work performed, professional experience, knowledge of the reality in the sector and connection with the subject matter of the study provides recognition of the expert knowledge of those participating in the study and guarantees the reliability of the obtained information. The selection of the public health care sector, from which the experts for the interview were recruited, was intentional and is directly related to the results of quantitative analyzes performed in the first part of the project.

The interview was overseen by observers, who were the members of the project implementation team, whose task was to provide additional explanations to the experts taking part in the study, expanding upon the formulated questions that did not cover all the experts' knowledge etc. An important task of the observers was also the registration of information obtained through the study, which was done in writing (with the consent of the experts participating in the interview). The basic method for recording the course of the examination was audio recording. At the same time, written records carried out by more than one person

\footnotetext{
${ }^{1}$ The article is the result of research carried out by the Central Mining Institute on behalf of "KADRA" Trade Union Agreement and the Trade Union Forum as part of the project entitled "A competent trade unionist - how to support employees in labor change processes", co-financed by the European Social Fund under the Operational Program: Knowledge Education Development 2014-2020. The orderer defined the cognitive area (demographic change) of the research, as well as identified the experts included in the research. The moderated group discussion took place on July 17, 2019, in Opole.
} 
increased the chance of capturing all the information provided by the experts and, at the same time, enabled the elimination of errors related to noting answers by comparison. The research topics did not require the preparation of supporting materials for experts and the methods used to conduct and record the focused group interviews, in accordance with the presented methodological guidelines, allowed to avoid a number of errors characteristic for qualitative research. Therefore, the collected material can be recognized as highly valuable.

The basis for the development of detailed research objectives was quantitative analysis (desk research), diagnosing the impact of demographic changes on the labor market and education, whilst also enabling appropriate targeting of research, determining its scope and the experts included in it. In this context, it should be noted that qualitative research serves the purpose of the following specific objectives, preliminary the determination of the state of knowledge of the surveyed experts on demographic change in a global perspective from the point of view of a knowledge-based economy - in conjunction with such megatrends as climate and technological change.

As noted in numerous pieces of work, three key global changes - which are climate, technological and demographic change - have forced the enterprises to adapt in the areas of operating principles, information methods and organizational models, in order to build sensitive solutions based on innovations that shape modern (smart) enterprises of the future (Borkowska, 1998, p. 33). In light of the changes outlined above, the biggest challenge for smart and innovative organizations is the need to anticipate the future, improve in the face of a changing environment, build solutions that respond to changes that may occur in the future and improve their competitiveness (Kubik, 2012, p. 36).

In turn, the objectives are:

- collecting expert opinions on the studied phenomenon and its diversity in the context of impact on the national labor market and education system at every level of education,

- obtaining the opinions of experts regarding changes they have observed in their environment, which have been caused by demographic changes - problems arising in enterprises and industry, in which experts operate, as well as the ways to solve them,

- diagnosing opinions on the positive and negative effects of demographic changes, along with defining the direction of their development - as well as assessing their impact on the labor market and education.

The results obtained from the research were used to determine whether or not the analyzed process threatens the development of the labor market and education system at every level of education. On the other hand, experts' opinions regarding concerns related to demographic changes allowed the formulation of in-depth conclusions regarding the development of processes related to demographic changes - which becomes particularly important in the context of the situation of the labor market and setting directions for the development of the education system. 


\section{Moderated discussion from the perspective of demographic conditions and forecasts}

Currently, the demographic phenomena permanently shape social relations in economically developed countries. This fact, together with the consequences resulting from it, have led to the emergence, in demography, of new theoretical hypotheses and research questions, directly related to the relationship between the number of births and deaths. Based on these relationships, a new approach has been created to describe these demographic phenomena, termed the "Second Demographic Transition". This approach distinguishes four characteristic determinants, which - according to D. van de Kaa, the creator of this theory - are (van de Kaa, 1987, p. 11):

- decreasing the importance of marriage as a form of human co-habitation for cohabitation,

- transition from family model: child with parents "the king-child with parents" to model parents with a child "the king-pair with a child",

- the transition from preventive contraception to conscious procreation,

- transition from homogeneous types of families and households to various forms.

As a result of changes and long-term forecasts, according to expert assessment, demographic changes will have a significant impact on the future shape of education and training systems. The most serious challenge is the need to adjust all levels of education to the population age structure resulting from demographic changes, as well as the need to improve people's competences by promoting the idea of lifelong learning. As a result of population aging, it should be noted that future European labor resources will come from significantly older members of the population than today. This is connected with another challenge, which is the need to update current training systems in order to adapt them to the needs of aging societies, from which a large percentage of employees will come from. The development and competitiveness of Europe will depend on the quality of their employment and their efficiency. An equally serious challenge is the aging of the teacher population. This process determines the need for providing high-quality qualified staff for the education and training system, together with the need to recruit new and talented employees in the face of market competition. In conclusion, demographic change is a significant challenge for numerous areas of public policy, such as family, labor market, social security and education. The identified challenges and areas of their impact are part of a broader spectrum of reflection that should focus on a holistic approach to the education system, which is a key determinant shaping human capital, in which - as forecasts indicate - by 2050 , people over sixty-five years old will constitute $20 \%$ of the total population of the whole Europe. Regardless of the social changes caused by the transformations described above, demographic changes will put enormous pressure on the pension and social security systems of the EU countries. If these processes are neglected - 
as shown by numerous studies - the EU threatens to reduce potential employment growth rates to extremely low levels of around 1\% per year (Krysiak, 2017, p. 82). This forecast clearly shapes the need for creating scenarios for developments in the labor market, including in the area of personnel needs. This claim is determined by, among others, the fact that the societies of developed countries are entering a phase, in which the proportion of professionally active to inactive persons is shifting towards the latter group. On the basis of these conditions, Poland's demographic situation definitely places it in the zone of dynamically aging societies.

In the coming decades, demographic trends will determine the shape of the economic model of the world and individual economies. Aging, still significant (though decreasing) number of "young" societies and countries, migration and spontaneous urbanization all necessitate appropriate adjustments to economic policies. Over the next few decades, countries with aging societies are determined to make efforts to maintain citizens' standard of living, develop new types of services, as well as ensure the continuity of social security systems and the sustainability of public finances.

A limited supply of economically active people and changes in the demand for employees (qualified and unskilled) may result in the intensification of global migration. Urbanization which creates incentives for economic development will, at the same time, increase pressure on food and water resources and, if uncontrolled, may cause excessive economic and social costs (Strategy for ... 2017, p. 20).

At the same time, competences related to the concept of the so-called silver economy, understood as a socio-economic system which, on the one hand, is focused on using the potential of older people on the labor market, whilst - on the other hand - taking into account their needs as consumers (Analysis of qualifications..., 2014, p. 37). As the silver economy grows, the productivity paradigm changes. Developed countries, if they want to maintain a standard of living and the level of GDP growth necessary for this purpose (2-3\% per year), must radically increase the productivity of their economies. Innovation is the only way. "McKinsey Quarterly" estimates that, in the United States, product and business innovation must account for at least $70 \%$ increase in productivity (Bisson et al., 2010). In Western European countries, every additional Euro produced must come from 100\% innovation. In Japan, due to the rapid decline in labor force, innovations must keep up with the resulting decrease in productivity, which means the need to achieve an increase of $160 \%$ from innovation. This means that a condition of effective response to development challenges related to demographic change must be a close link between the demand for competences and innovation.

In this context, attention should be paid to one of the most important - in the opinion of the European Commission - challenges facing Poland, which is the insufficient research and innovation system, as well as the low innovation potential of Polish small- and medium-sized enterprises (Position Paper, 2014-2020). As the Strategy for Renewed Development emphasizes, the biggest challenge for Poland will be to achieve the assumed level of expenditure on research and development activities (hereinafter $R \& D$ ), which is also a problem 
across the EU (Strategy for..., 2017, p. 45). In the light of these challenges, it should be emphasized that, in recent years, many changes have taken place in Poland, which have positively influenced the innovativeness of the Polish economy and the ability to think about innovation. There has been an acceleration of the EU technological catch-up process in enterprises, including by renewing the machine park, building new R\&D infrastructure, as well as strengthening the competences of staff implementing innovative projects. The way of thinking about innovations is also gradually changing. In addition to the use of ready technologies, enterprises see the need to develop their own solutions, including those based on the results of $R \& D$ works, and build a competitive advantage on them. In order to support these processes and concentrate resources on selected areas, key technologies - called the National Smart Specializations - on which public intervention was focused, were selected using analytical tools, such as technological foresight, and through constant cooperation with business and science (Strategy for..., 2017, p. 85).

Against this background, both the quantitative and qualitative change process has been shaped, regarding staffing needs. Unfavorable demographic changes and the related aging of the population, as well as increased migration away from Poland further weaken the perspective of providing the national economy with adequate, well-qualified and creative staff. Noting, for example, the time needed to complete university or high school - starting from the moment of making a decision about education in a chosen specialization - it seems that interdisciplinary recognition of staffing needs significantly supports the accuracy of educational decisions. In economic and social policy, recognizing and anticipating changes in the labor market is of particular importance, as was confirmed by numerous sources. As noted by E. Kryńska and E. Kwiatkowski, nowadays, every country implements a policy towards the labor market on behalf of and for society, consisting of influencing the supply and demand for work to maintain or restore balance. This takes into account the need to achieve the main objective of high employment and low unemployment. Due to the economic and social importance, as well as special employment functions, these activities are some of the most important in the area of economic policy (Kryńska et al., 2010, p. 1).

A lack of knowledge about the current and future situation of the labor market will certainly lead a high risk of error when developing assumptions regarding minimizing structural mismatches, which are the main source of high unemployment (Analysis of..., 2009, p. 4). This means that correct assessment of the conditions and the expected changes form an important basis for determining current and forward-looking tasks in the field of activities shaping the situation on the labor market (Hrynkiewicz, 2008, p. 9). In this context, it should be noted that modernization and restructuring processes occurring in the Polish economy play an important in relation to the changes in the structure of labor demand both in local labor markets and in the domestic market. Changes in the structure of labor demand require an appropriate adjustment of the labor supply through the development of employee qualifications and increasing their mobility, related to their readiness to take up work outside 
their current place of residence (Strukturalne niedopasowania..., 2015, p. 118). Based on the assessments and forecasts prepared, short-term and long-term programs have been prepared, that should lead to the minimization of the aforementioned negative phenomena occurring in the labor market.

The regularities and trends indicated above seem to clearly determine the issues of importance for scientifically shaped assessments and analyzes of labor markets. As indicated by past and present phenomena and processes, special importance in labor market policy should be attributed to the available form of support of the smooth transition of young people from education to the labor market and the possibly lengthy professional activity of people aged over 50. In view of the above objective, it should be clearly indicated that the observed demographic, economic and social trends will force the extension of the period of economic activity of Poles. Similar regularities can be observed in most of EU countries. The decision regarding longer activity can be forced (through the solutions of the pension system), it can also be stimulated by properly conducted social policy, in particular labor market policy. As European experience shows that the approach to this issue cannot be fragmented, only a holistic approach to the problem of active aging, which is part of the concept of the life cycle (also in this narrow dimension of professional activity), is a guarantee of success and Polish solutions should also evolve in this direction (Wojdyło-Prerisner, 2010, pp. 157-158).

\section{Research implementation - discussion}

Specification of the study objectives and the method chosen (moderated discussion) enables the characterization of the experts participating in the study to be recognized as representatives of national trade union organizations of nurses and midwives, including those holding the position of chairmen or vice chairmen and directly or indirectly related to the subject discussed. The main determinants of the selection of experts are the presented detailed research objectives, as well as the basis for the results of the first stage of work under the project on assessing the impact of demographic change on the domestic labor market and the education system (desk research). Representatives of nurses' and midwives' trade unions, directly or indirectly connected with management issues of trade union organizations in the public health sector, were invited to the discussion - as previously noted. The type of performed work, professional experience, knowledge of the realities prevailing in the sector and connection with the subject matter of the study enable the recognition of the expert knowledge of the individuals invited to the study and guarantee the reliability of the information obtained (Marszowski, 2019). 
Based on the specific objectives and definition, a set of theses and research questions was developed and presented to experts:

1. In your opinion, is Poland a country that is prepared for major demographic changes?

2. Which of the following determinants would you include for Poles, which have the most influence on the demographic structure:

- decreasing importance of marriage as a form of human cohabitation,

- transition from the family model: a child with parents "the king-child with parents" to parents with a child "the king-pair with a child",

- transition from preventive contraception to conscious procreation,

- transition from homogeneous types of families and households to diverse forms.

4. Is it true that instead of investing in the future of their children, parents are more focused on self-realization?

5. Is the national education system prepared for demographic changes?

6. Are national social and labor market policies taking on the challenges of demographic change and prepared to counter them?

7. Do the relevant state administration authorities have appropriate programs to define measures limiting the negative effects of demographic changes?

8. How can you assess the demographic and competence structure of the employees of the national economy - especially the most educated and specialized staff?

9. Is the age structure of employees in the Polish economy monitored on an ongoing basis?

10. Is there currently a shortage of employees in the national economy, including in particular - the most educated and specialized staff, which results from demographic changes?

11. Can there be problems in the functioning of the national economy in the near future resulting from the age structure and the shortage of employees, in particular specialist staff?

12. How do you assess the chances of filling the generation gap on the domestic labor market?

13. What features of the current and future population development of Poland (and its regions) will pose the greatest challenges for national and regional social and economic policy?

14. In view of the decreasing population of Poland and the majority of its regions, what further measures to support women's fertility (as the main culprit in the drop in the number of births) should be taken as part of the national population policy?

15. What kind of support system for seniors should be adopted in society?

16. Is there a need to monitor processes and activities and develop scientific research on the determinants of population development in Poland? 
Research was conducted by three experts (two doctors of social sciences and one with a master's degree in economics). A moderator, i.e. the person leading the discussion, prepared a list of questions related to the problem area of demography.

The experts participating in the study were informed about two legal regulations that obliged them to remain anonymous in the research, which were the Act on the Protection of Personal Data (Journal of Laws, 2018) and the Regulation of the European Parliament and the Council on the protection of individuals with regard to the processing of personal data and on the free flow of such data (hereinafter GDPR) (Regulation of the Parliament, 2016).

In light of all the questions raised, the experts expressed the below assessments and opinions. In the context of determining the structure of the Polish population in relation to the demographic change, the experts clearly stated that "demographic change leads to the decrease of the population". According to the experts, the process of population decline is particularly dangerous in the lower age cohorts, as it results in a lack of generational replacement and leads to an aging population, which is unprecedented in recent history. On this basis, experts concluded that "demographic change may lead, in the near future, to unpredictable and adverse changes in the public finance system - including social security". In this context, experts were asked to assess the country's level of preparation for such severe demographic changes. In the first of the assessments, an expert stated that "Poland, as a country, is not prepared for demographic changes". According to the experts, there are many reasons for this. As one of the experts emphasizes, "one of them is the increase in the quality of life in the country. Poles are becoming - similar to the rich societies of Western Europe - an increasingly rich and modern society. As examples show, in developed societies, two features indicated in these large social groups determine the process of depopulation and aging of the population". In further statements, the experts emphasized that "the lack of preparation of the state for demographic change is the result of the fact that it has never prepared for such change before". As one expert notes, "I've never heard of any preparations related to demographic change in my life. The only program I know is the $500+$ program" 2 .

An important factor affecting the size of demographic change is the gross domestic product (GDP). According to one of the participants in the discussion, "GDP in Poland is one of the highest in Europe. In principle, all European countries strive for the highest level of GDP. However, it should be noted that the growing gap in the labor market - determined by

\footnotetext{
${ }^{2}$ The "Rodzina $500+$ " (Family $500+$ ) program is a financial instrument for supporting families. The program came into force on April 1, 2016, and contributed to a significant improvement in the financial situation of families, strengthened them and gave priority. In 2015, total state budget expenditure on families amounted to $1.78 \%$ of Gross Domestic Product. In 2017, this increased to 3.11\% of GDP. This was an increase of $75 \%$. The "Family $500+$ " program pursues three basic goals: it increases the number of births (the fertility rate increased from 1.29 in 2015 to 1.45 in 2017) reduces poverty, especially among children (in 2015-2017, extreme poverty fell from $6.5 \%$ to $4.3 \%$ ) and is an investment in the family. Pursuant to the changes introduced in the "Family $500+$ " Program, from July 1, 2019, parental benefit is granted to every child up to the age of 18 , regardless of the income of the family. The extended formula of the Program improves the quality of life of all Polish families with dependent children and complements the comprehensive state policy towards families. More: https://www.gov.pl/web/rodzina/rodzina-500-plus.
} 
demographic change - can reverse this favorable trend. Are we prepared for it?" In the context of experts, the "wave of labor migration" is important in the context of an Eastern European country, which maintains domestic production at a high level. However, this will not last forever. Today, new solutions and instruments should be sought to maintain GDP at a high level during the demographic change phase. If this is not done, there could be enormous consequences. The aging of the population is, above all, a huge challenge to public health protection. Is it prepared for this change? The experts answered this question: "Somehow it will be". As one of the discussion participants emphasizes, "the internal situation itself, lasting for several years, is bound to the closure of branches with this specialty in connection to the related errors with the cessation of education of future internists, currently resulting in their huge deficit". As another participant in the discussion stated, "the described situation related to doctors of internal medicine generally refers to serious deficits related to the profession of a doctor, nurse and midwife. This creates a huge surplus of patients compared to medical staff. We only have seven geriatricians today in the Opolskie Voivodeship. One of the instruments that could improve this unfavorable situation could be a system supporting Families in order to care for a geriatric patient who does not have one". As one expert states, "there are families who would like to look after patients at home, but do not have the appropriate competences, they do not know where to look for help and support in this area". A very important problem in the opinion of those who participated in the discussion is a serious deficit of geriatric wards. As one participant stated, "there are only two geriatric wards in the entire Opolskie Voivodeship. There is a small number of beds in relation to needs". The experts also pointed to the most serious problem which is - in their opinion - the lack, in the National Health Fund budget, of adequate measures to the scale of the phenomenon of the aging of the population of the country to ensure preventive and medical treatment in this population". Nowadays, nurses have great opportunities for professional development and running geriatric wards. The problem in this area is that contracting a geriatric service in the National Health Fund is almost impossible". In the conclusion of this part of the discussion, one expert states that "GDP is too small for old people. Nobody wants old people - nobody needs them. Long-term home care is not enough". Another participant notes that "We, nurses, are getting older. There are fewer and fewer of us. What trade unions have won for nurses is not enough. I recently met with nurses who no longer work in our country, who say how much they earn and that the country, in which they work, will accept any number of nurses. This regularity is connected with the Opolskie Voivodeship, which is close to the Polish-German border, and half of the region's residents speak fluent German. That is why, Polish nurses are eager to migrate, knowing how much they can earn. On the other hand, while staying in the country, we often do half the work of a doctor. If this situation persists, there will be no nurses, there will be old age - lots of old age - which nobody will want". In highly developed countries, the offer of care and assistance for the elderly is well-supported, with huge amounts of resources from the state 
budget. In our country, we have been struggling for years with problems associated with retirement homes.

It should be noted that the Opolskie Voivodeship is aging the fastest amongst all the voivodeships in Poland. In the Opolskie Voivodeship, an undertaking called the "Demographic Park", executed from the beginning of 2020, was extremely interesting in the opinion of experts. The goal of this program was to integrate all voivodeship and local policies, as well as activities and initiatives to prevent an aging population within the voivodeship. In this context, experts said that "there are currently many factors that lead to the contestation and disappearance of the traditional family model, i.e. mother, father and child. A change in the family model from the traditional type to a task-oriented type can be observed, as well as a change from the model of marriage with children to a model of partners and children. Moving away from preventive abortion in favor of conscious procreation and from marriage to partner". According to the discussion participants, "these are processes that we cannot defend against". In the experts' opinion, the most important determinant of changes taking place is "a change in the family model, which implies other processes and, as a result, the aging of the society".

Another issue raised in the discussion was related to gender "ideology", one expert notes that "a few years ago, they tried to introduce gender 'ideology' into schools, so that a child could not recognize whether he/she was a boy or a girl? Such activities cannot be introduced to kindergartens or schools without informing the parents and getting their consent. It would be better if the children were made aware of the role that their parents play as partners who accompany them in their development". According to experts, the described condition carries numerous threats. As one of the discussion participants states, "we are increasingly dealing with a situation, where an underage child is suing their parents in order to receive compensation, e.g. for ill-treatment or restriction of their freedom". Another expert disagreed, stating that "I would prefer that a child could sue their parents, rather than being beaten at home all their life and being unable to say anything". Another perception of this problem was perceived by another participant, who noted that "the discussed problem results from the attitudes of young married couples and parents who are lost in the flow of information. They are unable to properly receive and interpret this information. An example would be a young mother who, after having a child in my ward, despite the huge amount of information sources - Wikipedia, Google etc. - doesn't know how to feed a baby". As the experts note, "a child from conception together with parents is lost. It remains without authority. It has no clear rules of conduct and behavior. The family model is disturbed. The family is deprived of grandparents who have life rules that they could pass onto young parents and grandchildren. The exchange of information on life patterns does not have its source in the family, but on the Internet". Another expert notes that "[I have been] working for 30 years in a pediatric ward. When I started, my department was closed. Parents could not visit their children during hospitalization. Compared to the present day, children were much more ill and we, nurses, were alone with them. At the moment, the parent is with the child throughout the treatment of the disease. Today, in the ward, 
I not only have a patient, but all of their family. Therefore, change is permanent. It is still developing, and one should adapt and accept it".

Demographic change is forecasted in many variants and by numerous institutions. Experts in this area have paid particular attention to the "process of intensive change of age, in which the procreation decision is made". One expert states, "today, the birth of a child by a woman aged 33 is a natural phenomenon. The man makes the decision to procreate later, often after 35 years of age". This phenomenon has a huge impact on the labor market and the education system. As a result of these changes, according to experts, the depopulation of Poland and dynamic increase in labor migration from Eastern European countries can be expected. Therefore, it is important to see demographic changes through the lens of the European Union, through joint actions and mutual support. "Poland is not a desert island", as one discussion participant emphasizes. Although, in one of the expert statements, there was a prediction, in which the expert expects that "we cannot count only on the Union. It has its own interests. Therefore, we must take care of our own affairs. Later, we can count on the help of our neighbors". A major part of the discussion focused on minimizing demographic change by a conscious and organized migration policy. As one expert notes, "I am in favor of bringing nurses to Poland, but under several conditions. The first is that they have appropriate education and professional experience. The ability to communicate in Polish is important". The expert attaches great importance to "voluntary training undertaken by a person migrating to Poland in the field of cultural and social conditions". According to experts, "migration policy under no circumstances may be based on spontaneous and uncontrolled phenomena. Cultural proximity is the most important factor. This factor will determine the possible success or failure of a national migration policy. Therefore, migration is an essential process, without which the national economy will not be able to develop fully". The main problem in the opinion of experts in this area is the issue of the length of stay of the migrants and their further migration to the more developed countries of Western Europe. One expert, while discussing this issue, stated that "it is up to us, how long migrants stay in our country. Let migrants work on the same terms as us. Do not let them be discriminated against in the workplace by being paid less for doing the same job as Poles and in jobs that many Poles do not always want to do. We expect the state to actively join the process with a migration policy appropriate to the ongoing changes in the labor market". In the context of migration policy in Poland, experts have noted that "Migration policy is instrumental and directed solely at determining numerical parities of permissible economic migration to Poland. The result of this action was the blocking of a wave of several thousand migrants from North Africa and allowing over one million migrants from Ukraine to enter Poland". According to the experts, migration also concern Poles. As the participants of the discussion note, "huge number of well-educated nurses leave Poland after graduation. Only those, who have started families and do not want to leave them remain. This is a huge loss for the country, the national economy and the labor market". Migrants - according to experts start a family at the migration destination and don't return to the country. "A key factor which 
has already been mentioned and determines the level of migration are wages. One expert states that "(we, trade unions) by agreeing on wages of gross four thousand two hundred PLN for a nurse with higher education and specialization, we shot ourselves in the foot". In the final conclusion, the experts emphasized that "despite all the errors and weaknesses related to the political transformation of the state, a civilization leap was made. The wellbeing of Poles and the quality of life are incomparable to the early 1980s".

In the summary of the discussion, each participant was asked by the teacher to briefly answer the question: are they afraid of demographic change? If so, why? The first expert said he was afraid of demographic change. As justification, he stated that he is primarily afraid of the disappearance of the traditional family, a fall in births and decreased fertility. As a result, the aging process will intensify and the finances securing social needs will be insufficient. Another expert agreed with this opinion, emphasizing that "I do not know my future, but I think I am afraid. I am a nurse myself and I will also grow old. I am afraid that, then, there will be no one to look after me". Other experts focused entirely on the answer "I'm afraid". Another expert said "I am most afraid of the transition period. When we start doing anything to change this situation. I think it will be too late and it will certainly be worse than today". There was also a concern from the next expert, as well as the fear of demographic change. The expert, in the justification of his assessment, states that "I am of retirement age. 30 years ago, when I was starting work, nobody gave me a chance to save for my retirement. It is too late now to change anything. That's why I think that my standard of living and social status will be miserable in my retirement". Another expert stated that he is "not afraid of depopulation". Justifying his position, he emphasizes that "society is getting richer. Today, we aspire to be the bestdeveloped economy and a rich country. Poland will manage to maintain its economic boom and maintain its high level of GDP". Another expert said that "I am afraid of demographic change in one aspect: will I see my grandchildren?" A similar statement was expressed by another expert, stating that "even when my daughter is sitting here with me, because I do not know what the future will be, I also don't know if I will live to see my grandchildren. We live in times of stress and various diseases, as well as numerous duties that we cannot cope with". Another expert states "I am also afraid. Most of all, that soon there will be no one to work for our pensions". Another expert stated that "I'm not afraid of demographic change. We have a wise society. Our children are well-educated. We will deal with this problem. Only the European Union should not interfere with this". The next assessment is dominated by concerns related to demographic change. The participant, in her opinion. focused on her profession, stating that "me and my friends are already professionally burned out, tired. We are just over fifty and we don't know what's in store for us, except for low pensions". Discussion participants expressed a similar tone, particularly emphasizing their concerns about the future of their children. Yet another expert perceives it differently, emphasizing "I live on a tiny street, where seven widows have recently appeared. Widows do not have income as high as residents of the rich countries of the Western Europe. They must make ends meet each month. They are afraid of sickness in 
old age. I am afraid that this condition will not improve. It will rather get worse as a result of aging". All the assessments and forecasts made in the discussion constitute the basis authorizing the formulation of recommendations and final conclusions - in which special significance was assigned to the utilitarian dimension of the research.

\section{Recommendations}

The following recommendations for organizations and institutions of social dialogue in particular trade unions - are aimed at strengthening their knowledge and position in an informed public debate on the effects of the transformation of demographic change.

In response to the process related to demographic changes - and in light of their future effects - it seems justified to include in the program documents of trade unions and organization of the social dialogue forum a new mission with the following recommendations: "Bearing in mind the process of demographic change, trade unions and further organizations of the social dialogue forum in their missions will work to reduce the negative effects of demographic change - in particular in the situation of an aging population - and strive to reverse this trend across the country, as well as local communities, help to improve generational replacement and strengthen active social policy and the labor market, as well as the education system at all levels of education". If the country is not prepared for demographic changes, trade unions and social dialogue forum organizations should take action to start a national debate on demographic changes, in particular the depopulation Poland. At the same time, the debate should include the expansion of the 500+ program with further measures to strengthen the model of a traditional multi-generational family, based on the "+ children" model. Increased awareness in the area of the Gross Domestic Product impact on family safety and its ability to flourish among employees associated in trade union organizations and other organizations of the social dialogue forum is extremely important. Therefore, it is necessary to consider conducting an information campaign and training cycle about the need to create the highest level of GDP in the country. It seems justified to create, within trade unions and other organizations, a forum for expert teams to have social dialogue that can influence the creation of:

- conscious and forward-looking national migration policy, conducive to a sustainable and effective mobile migration of people from Eastern Europe in the context of the country's economic growth,

- conscious and forward-looking national health policy, organized so as to train qualified staff, eliminate staff deficits amongst doctors, nurses and midwives, as well as develop geriatrics and gerontology, as well as health care infrastructure, 
- conscious and forward-looking policy of supporting families providing care to a geriatric patient, in particular the development of an information campaign indicating the benefits of this measure, a specialized training program for such families, solutions enabling support from public finance and launching a "Family and a Geriatric Patient" public helpline.

The need to engage trade union organizations and other organizations of the social dialogue forum to create and program the activities of the National Health Fund in the area of geriatric prevention and preventive treatment is also highly important. It is equally important to consider the involvement of trade unions and the organization of the social dialogue forum in activities that can change adverse phenomena, related to demographic change, such as:

- clearly disturbed feminization rate,

- serious shortages of women in the age group 29-31 (age of highest matrimonial activity),

- unnatural number of women in the oldest age groups,

- a clear decrease in the number of marriages,

- a significant decrease in the number of births,

- negative birth rate,

- extremely low fertility,

- extremely low gross reproduction rate,

- very low demographic dynamics ratio.

It will be very important for trade unions and the organization of the social dialogue forum to engage in activities aimed at securing decent living conditions for people moving from activity to inactivity as a result of demographic change, defined as demographic depression. In this light, it is worth noting the need to look for solutions that will allow trade unions and social dialogue forum organizations to limit:

- unemployment among people with long seniority,

- discrimination in the labor market on grounds of age,

- increase in the labor costs of older employees,

- pension schemes that encourage relatively early retirement,

- relatively low level of education of the elderly,

- bad health condition,

- problems adapting to new conditions,

- work fatigue,

and strengthen:

- the demand of families for the work of aging people,

- possibilities of caring for grandchildren, spouse or elderly parents,

- training for older workers to acquire new skills and qualifications,

- assigning more value to free time. 
It is equally important that trade union organizations and social dialogue forums need to seek solutions that reduce: the shrinkage of potential labor force resources as they grow older and the increasing burden on working-age people in the post-working age. In this context, consideration should be given to the need for trade union organizations and the social dialogue forum to be involved in developing guidelines for policy preparation programs at the local, provincial, national and EU levels, which respond to the challenges arising from the phenomenon of old age, including: the pursuit of trade unions and the organization of a social dialogue forum to give public employment service a leading role in the work on preparing thematic proposals for social activation and professional seniors. Consideration by trade unions and organizations of the social dialogue forum of developing a catalogue of proposals for actions strengthening the participation of seniors in making decisions shaping their present and future (Senior Council) is important. Propos the trade union organizations and the forum for the development of a national intergenerational integration program, in particular based on the diversity management method and limiting the intergenerational information gap. Attempts by trade unions and organizations of the social dialogue forum to develop an educational program presenting the economic and social consequences of demographic depression. The creation of forums to prepare a package of activities dedicated primarily to women of senior age by trade unions and forum social dialogue. The aspiration of trade unions and social dialogue forum organizations to prioritize education and health issues in activities promoting the social and professional activity of seniors. An attempt by trade unions and social dialogue forum organizations to prepare an information campaign presenting the effects of aging on the consumption model, public finances, health and social protection policies, as well as migration. An attempt by trade unions and social dialogue forum organizations to develop guidelines for a program to counteract marginalization, differentiation and social exclusion of seniors. The undertaking of public debate on the security policies implemented by state institutions, through full participation in the labor market, of better living conditions and fuller social inclusion of the elderly, thus supporting social and professional activity giving them greater fullness of life, by the trade union organizations and social dialogue forum. In the final recommendation, the trade unions and social forum organizations should indicate the need for urgent strengthening and development of social capital among the elderly.

\section{Conclusions}

In light of all the research results and proposed recommendations, it is worth emphasizing, once again, that demographic trends in Poland since the beginning of the 1990s indicate multidimensional unfavorable changes, which are visible in the structure of the population (Marszowski, 2019, pp. 229-243). They are expressed in a decrease in the number of inhabitants 
and the consolidation of a deeply negative natural increase, maintaining a high negative balance of internal and foreign migration for permanent residence, as well as a low level of population growth per 1000 members of the population. This is accompanied by a high decline in the preworking age population, particularly a large decrease in the working-age population and a very high increase in the post-working age population. All this indicates unfavorable development directions of the structure of the Polish population. The trends which are unfavorable to the development of the population structure are also confirmed by the changes occurring in natural movement. The key determinants of adverse changes in the natural movement of population were the persistence of the low number of marriages, as well as the small number of live births per 1000 members of the population, very low birth rate, extremely low fertility rate and low gross reproduction rate. The indicated multi-sectional trends and changes in the total balance and in the natural movement of the population are the source of the process of turning the age pyramid. The result of this process is dynamic and sustainable aging of the population (Denton, 2014, pp. 71-98).

As a result of the regressive nature of demographic change, the process of demographic aging is increasing, which will affect the situation on the labor market. Occupational inactivity of numerous (high-growth) years of retirement age, following a weak supply of labor from a small number of (low-volume) years reaching working age, can lead to various difficulties in the labor market - e.g. in obtaining labor, both in a quantitative, as well as qualitative sense. In light of the observed and anticipated changes, it is important to emphasize the importance of influencing the population structure of the country, waving highs and demographic lows, extending the lowland phase of the late 1980s for subsequent years (the transformation period), as well as the impact of the systemic economic transformation and Poland's accession to the EU in the spatial, demographic, social, economic and infrastructural sphere, which highlighted numerous development problems. As noted by J. Runge, these trends require multi-faceted activities in both the socio-economic and spatial spheres. Diagnosis - or actually constant monitoring - of population changes is only a starting point for identifying the objectives of activities, their evaluation, hierarchization, as well as taking into account the implementation conditions of population policy. The starting point should also be greater activity of state administration bodies in creating employment policy. The labor market is the basis for further activities in the housing sphere and in social infrastructure. Systemic diagnosis and mitigation of depopulation tendencies is one of the main factors of success of population policy during the period of demographic decline (Denton, 2014, pp. 71-98). In addition to this challenge, new problems are now emerging in the field of human resource management as a consequence of demographic and economic changes, in which the national education system and national enterprises are participants. One such challenge is the constant need to adapt education to the processes taking place within the labor market, which often diverge from the directions of economic development and the needs of the enterprise. That is why skillful recognition of staffing needs expected in the economy is so important. As Juchnowicz notes, the economy and 
its changing structure shape both the quantitative and qualitative staffing needs, qualifications and competence of labor resources. The employee of the $21^{\text {st }}$ century, in the demographic change phase, must be a highly educated expert (Juchnowicz, 2007, pp. 40-46). In this context, it should be noted that the expected changes, by 2050, will force - especially - the regional and local public institutions to take specific roles and face challenges resulting from demographic change. It is, therefore, important that these institutions receive the support of public authorities. On the other hand, actions taken should be preceded by consultations, and these should be accepted by the public.

\section{References}

1. Analiza kwalifikacji i kompetencji kluczowych dla zwiększenia szans absolwentów na rynku pracy (2014). Warszawa: Agrotec Polska Sp. z o.o.

2. Analiza regionalnego rynku pracy. Podręcznik prognozowania (2009). Katowice: Wojewódzki Urząd Pracy w Katowicach.

3. Bisson, P., Stephenson, E., Viguerie, S.P. (2010). Global Forces. McKinsey Quarterly, June.

4. Borkowska, S., Bohdziewicz, P. (1988). Menedżer u progu XXI wieku. Łódź: Wyższa Szkoła Humanistyczno-Ekonomiczna.

5. Denton, A. (2014). Przez ciemność w stronę jaśniejszej przyszłości, [in:] I. Palacios-Huerta (ed.), Gospodarka za 100 lat. Warszawa.

6. Dz.U. 2018 poz. 1000 Ustawa z dnia 10 maja 2018 r. o ochronie danych osobowych.

7. Hrynkiewicz, J. (2008). Starzenie się ludności polskiej a system ubezpieczeń społecznych. Biuletyn Rządowej Rady Ludnościowej, nr 53.

8. Juchnowicz, M. (2007). Polityka edukacyjna wobec potrzeb rynku pracy, [in:] P. Wachowiak, M. Dąbrowski, B. Majewski (eds.), Ksztattowanie postaw przedsiębiorczych a edukacja ekonomiczna. Warszawa: Fundacja Promocji i Akredytacji Kierunków Ekonomicznych.

9. Kaa, van de, D.J. (1987). Europes Second Demographic Transition. Population Bulletin, 42, 1. Washington: Population Reference Bureau Inc.

10. Kryńska, E., Kwiatkowski, E. (2010). Polityka państwa wobec rynku pracy: idee ekonomiczne i rzeczywistość. Polityka Społeczna, nr 5-6. Warszawa: IPiSS.

11. Krysiak, I. (2007). Wyzwania współczesnego rynku pracy, [in:] J. Tokarz (ed.), Rynek pracy a osoby bezrobotne 50 plus. Bariery i szanse. Warszawa: Wyd. Akademia Rozwoju Filantropii w Polsce. 
12. Kubik, K. (2012). Współczesne przedsiębiorstwa wobec wyzwań globalnej konkurencji. Zeszyty Naukowe Uniwersytetu Przyrodniczo-Humanistycznego w Siedlcach, Nr 92. Seria: Administracja i Zarzadzanie. Siedlce.

13. Marszowski, R. Megatrendy demografia. Raport z badania FGI, http://www.kadra.org.pl/ wp-content/uploads/2019/06/Demografia-raport-FGI.pdf.

14. Marszowski, R. (2017). Regres demograficzny w województwie śląskim. Źródła i następstwa. Humanum, $n r$ 25(2). Warszawa: Instytut Studiów Międzynarodowych i Edukacji.

15. Matusiak, M. (2006). Zawody przyszłości, [in:] G. Gromada, M. Matusiak, M. Nowak, (eds.), Innowacje i przedsiębiorczość dla przyszłości. SOOIPP Annual-2006. Łódź-PoznańWarszawa-Wrocław.

16. Position Paper Komisji Europejskiej (Stanowisko służb Komisji w sprawie opracowania umowy o partnerstwie i programów w Polsce na lata 2014-2020).

17. Rozporzadzenie Parlamentu Europejskiego i Rady (UE) 2016/679 z dnia 27 kwietnia 2016 r. w sprawie ochrony osób fizycznych $w$ zwiazku z przetwarzaniem danych osobowych $i w$ sprawie swobodnego przepływu takich danych oraz uchylenia dyrektywy 95/46/WE (ogólne rozporządzenie o ochronie danych).

18. Schlotter, M., Schwerdt, G., Wößmann, L. (2008). The Future of European Education and Training Systems: Key Challenges and Their Implications.

19. Strategia na rzecz Odpowiedzialnego Rozwoju do roku 2020 (z perspektywa do 2030 r.). Dokument przyjęty uchwałą Rady Ministrów w dniu 14 lutego 2017.

20. Strukturalne niedopasowania na rynku pracy (2015). Polska 2015 raport o stanie gospodarki. Warszawa: Ministerstwo Gospodarki.

21. Wojdyło-Preisner, M. (2010). Ewolucja programów zatrudnienia, [in:] Z. Wiśniewski, K. Zawadzki (ed.), Aktywna polityka rynku pracy w Polsce $w$ kontekście europejskim. Toruń: Wojewódzki Urząd Pracy, Uniwersytet Mikołaja Kopernika. 